\section{Prémio Alberto Romão Dias Atribuído a João Rocha}

\author{
João Rocha, Professor Catedrático de Química na Uni- \\ versidade de Aveiro e Diretor do Instituto de Materiais \\ de Aveiro-CICECO, foi o vencedor da edição de 2021 do \\ Prémio Alberto Romão Dias. Este prémio, instituído pela \\ Sociedade Portuguesa de Química (SPQ) em 2009, é \\ atribuído bienalmente a um químico que se tenha dis- \\ tinguido pela alta qualidade, originalidade e autonomia \\ do trabalho de investigação, desenvolvido em Portugal, \\ na área de Química Inorgânica e Organometálica. \\ Os interesses científicos do Professor João Rocha \\ situam-se maioritariamente na área dos nanomateriais \\ inorgânicos funcionais e híbridos orgânico-inorgânico \\ e as suas múltiplas aplicações, e métodos de caracte- \\ rização dos materiais, incluindo RMN de estado sólido. \\ Recentemente, foi publicada uma Interação Química \\ com o premiado, onde se fala sobre o seu percurso \\ académico (Química, 2020, 44, 89-93). \\ O Prémio será entregue durante a conferência \\ da Divisão de Química Inorgânica e Bioinorgânica da \\ SPQ (13ibcc.events.chemistry.pt), onde o premiado \\ proferirá uma Lição Convidada.
}

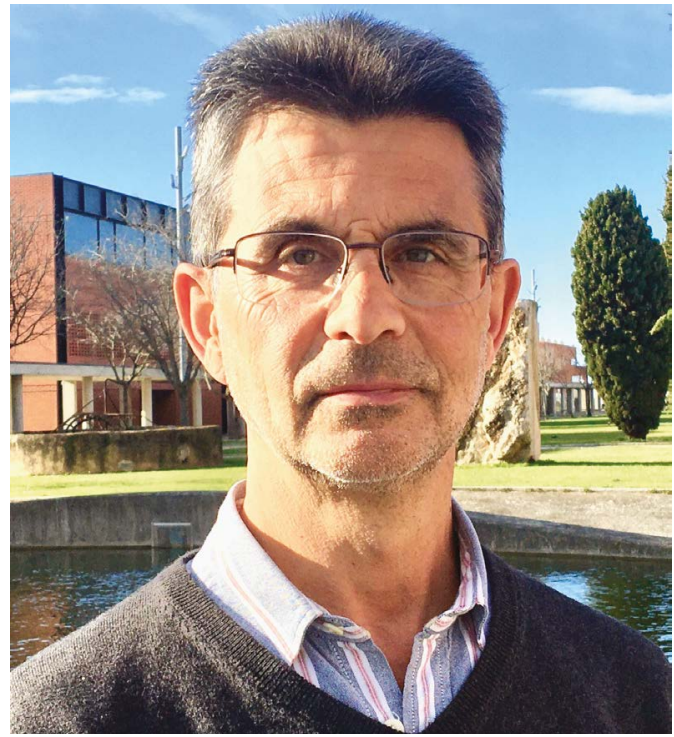

A lista de todos os vencedores do Prémio Alberto Romão Dias pode ser consultada em spq.pt/ premios/romao-dias/lista.

Bruno Machado

brunofm@fe.up.pt

\section{Prémio Luso-} Francês 2021 para o Professor Pierre Dixneuf

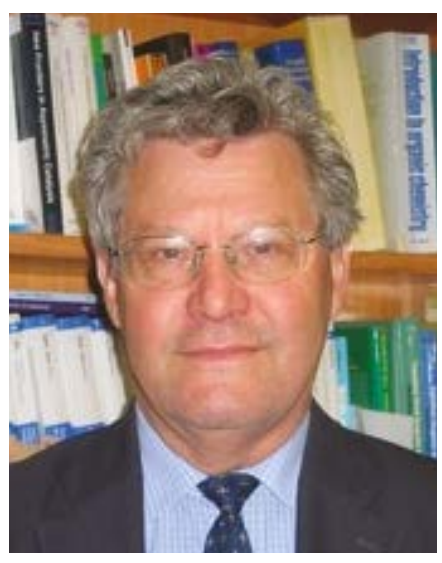

Pierre Dixneuf, Professor Investigador Emérito da Universidade de Rennes, França, foi galardoado com o Prémio Luso-Francês 2021, prémio instituído pela SPQ e pela Sociedade Francesa de Química, pelo seu notável trabalho e pelos fortes laços estabelecidos com os químicos portugueses.

As suas principais áreas de investigação envolvem a ativação/funcionalização da ligação $\mathrm{C}-\mathrm{H}$ para ligações C-C e C-heteroátomo através de reações de acoplamento cruzado, catalisadores de metátese de olefinas e aplicações de óleos vegetais, catálise para processos seletivos e química fina através de transformações catalíticas de alcinos, desenvolvimento de catalisadores de ruténio e novos catalisadores organometálicos ricos em carbono.

O prémio será entregue durante o XXVII Encontro Nacional da SPQ que se realizará em Braga de 14 a 16 de julho de 2021. A lista de todos os vencedores do Prémio Luso-Francês pode ser consultada em spq.pt/premios/luso-frances/lista.

Bruno Machado

brunofm@fe.up.pt 